\title{
Implementasi Neural Fuzzy Inference System dan Algoritma Pelatihan Levenberg-Marquardt untuk Prediksi Curah Hujan
}

\author{
Nola Ritha* ${ }^{1}$, Retantyo Wardoyo ${ }^{2}$ \\ ${ }^{1}$ Pasca Sarjana Ilmu Komputer, FMIPA UGM, Yogyakarta \\ ${ }^{2}$ Jurusan Ilmu Komputer dan Elektronika, FMIPA UGM, Yogyakarta \\ e-mail: *11nola.ritha@mail.ugm.ac.id, ${ }^{2}$ rw@ugm.ac.id
}

\begin{abstract}
Abstrak
Prediksi curah hujan dapat digunakan untuk berbagai kepentingan dan keakuratan dalam memprediksinya menjadi penting dalam berbagai hal. Dalam penelitian ini, data prediksi curah hujan yang digunakan adalah data curah hujan harian dari tahun 2013-2014 pada stasiun pengamatan Putussibau Kalimantan Barat. Prediksi curah hujan ini menggunakan empat parameter yaitu rata-rata suhu, kelembaban udara, kecepatan angin dan tekanan permukaan laut.

Penelitian ini dilakukan untuk mengetahui kinerja Neural Fuzzy Inference System dengan algoritma Levenberg-Marquardt untuk prediksi curah hujan. Logika fuzzy dapat digunakan untuk menyelesaikan variabel linguistik yang digunakan pada aturan curah hujan. Sedangkan jaringan syaraf tiruan memiliki kemampuan untuk beradaptasi dan kemampuan proses belajar, dikarenakan untuk mengenali pola data dari masukan sebelumnya dalam memprediksi curah hujan dibutuhkan suatu pelatihan. Dan Algoritma pelatihan Levenberg-Marquardt digunakan karena kefektifan dan kecepatan konvergensinya.

Hasil penelitian menunjukkan dari lima model NFIS-LM yang dikembangkan dengan menggunakan berbagai fungsi keanggotaan diperoleh bahwa model NFIS-LM dengan dua belas fungsi keanggotaan dan menggunakan empat input yaitu: suhu, kelembaban udara dan kecepatan angin dan tekanan permukaan laut memberikan hasil yang terbaik dengan nilai MSE sebesar 0.0262050. Jika dibandingkan dengan model NN-Backpropagation, model NFIS-LM menunjukkan akurasi yang lebih rendah. Hal ini ditunjukkan dari MSE yang dihasilkan dimana model NN-Backpropagation menghasilkan MSE sebesar 0.0167990.
\end{abstract}

Kata kunci-Levenberg-Marquardt, Neural Fuzzy Inference System, Prediksi Curah Hujan

\begin{abstract}
Rainfall prediction can be used for various purposes and the accuracy in predicting is important in many ways. In this research, data of rainfall prediction use daily rainfall data from 2013-2014 years at rainfall station in Putussibau, West Kalimantan. Rainfall prediction using four parameters: mean temperature, average humidity, wind speed and mean sea level pressure.

This research to determine how performance Neural Fuzzy Inference System with LevenbergMarquardt training algorithm for rainfall prediction. Fuzzy logic can be used to resolve the linguistic variables used in rule of rainfall. While neural networks have ability to adapt and learning process, due to recognize patterns of data from input need training to prediction. And Levenberg-Marquardt algorithm is used for training because of effectiveness and convergence acceleration.

The results showed five models NFIS-LM developed using a variety of membership functions as input obtained that model NFIS-LM with twelve of membership functions and use four inputs, such as mean temperature, average humidity, wind speed and mean sea level pressure gives best results to predict rainfall with values Mean Square Error (MSE) of 0.0262050. When compared with model NN-Backpropagation, NFIS-LM models showed lower accuracy. It is shown from MSE generated where model NNBackpropagation generate MSE of 0.0167990.
\end{abstract}

Keywords - Levenberg-Marquardt, Neural Fuzzy Inference System, Rainfall Prediction 


\section{PENDAHULUAN}

$\mathrm{C}$ uaca dan iklim merupakan hal yang sangat berpengaruh dalam kehidupan sehari-hari, seperti dalam bidang pertanian, industri dan transportasi. Salah satu faktor yang berpengaruh terhadap tipe iklim adalah curah hujan. Curah hujan merupakan ketinggian air yang terkumpul dalam tempat yang datar, tidak menguap, tidak meresap dan tidak mengalir [1]. Besarnya curah hujan yang terjadi tidak dapat ditentukan secara pasti, namun dapat diprediksi atau diperkirakan. Prediksi curah hujan sangat berdampak dalam berbagai bidang baik secara langsung maupun tidak langsung. Ketepatan dalam memprediksi curah hujan dapat digunakan untuk berbagai kepentingan.

Bidang meteorologi seperti prakiraan cuaca maupun curah hujan umumnya melibatkan konsep, prinsip, dan metode untuk menangani model penalaran yang menggunakaan perkiraan daripada yang sebenarnya. Dalam beberapa tahun terakhir, logika fuzzy telah menarik perhatian terhadap penanganan semacam ini [2]. Kemampuan menangani ketidakpastian menjadikan logika fuzzy sebagai potensi yang besar untuk perkiraan cuaca. Logika fuzzy merupakan cara cerdas yang dapat digunakan untuk menangani ketidakjelasan yang sering dihadapi dalam bidang perkiraan meteorologi serta dapat menggabungkan pengetahuan ahli dalam model matematika dalam bentuk sistem inferensi fuzzy serta cocok digunakan untuk penalaran perkiraan dengan menggunakan fungsi keanggotaan dan aturan [3]. Teknik ini telah banyak diterapkan untuk banyak masalah meteorologi seperti jangka panjang peramalan curah hujan [4].

Perkembangan model cuaca numerik seiring dengan perkembangan kemampuan komputasi telah menjadi perhatian dalam beberapa tahun terakhir [5]. Banyak cara yang dapat dilakukan untuk memprediksi besarnya curah hujan disuatu tempat, salah satunya adalah menggunakan teknik jaringan syaraf tiruan. Jaringan syaraf tiruan merupakan salah satu metode prediksi yang diakui keunggulannya, terutama untuk prediksi yang melibatkan banyak parameter yang bekerja secara simultan dengan bentuk hubungan fungsional yang tidak simultan [6].

Jaringan syaraf tiruan memerlukan suatu pelatihan atau pembelajaran dalam memproses input yang diberikan. Banyak metode lain telah dikembangkan untuk melakukan pelatihan jaringan syaraf tiruan. Algoritma Levenberg-Marquardt merupakan algoritma pelatihan yang sangat efisien untuk pelatihan jaringan dengan ukuran jaringan yang kecil hingga jaringan yang tidak terlalu besar dengan menggunakan metode Backpropagation jaringan syaraf tiruan [7]. Berdasarkan penelitian terdahulu menunjukkan bahwa algoritma Levenberg-Marquardt adalah algoritma yang cepat dan memiliki konvergensi yang stabil [8]. Penelitian prediksi curah hujan menggunakan jaringan syaraf tiruan dan algoritma pelatihan Levenberg-Marquardt telah dilakukan dibeberapa penelitian [9,10]. Agoritma pelatihan Levenberg-Marquardt juga akan digunakan pada penelitian ini.

Seiring dengan perkembangan teknologi, semakin banyak bermunculan metode-metode yang dapat digunakan untuk melakukan prediksi curah hujan dengan menggunakan jaringan syaraf tiruan yang di hybrid dengan metode lain seperti yang dilakukan oleh penelitian [11]. Sejalan dengan penelitian [11], penelitian [12] mencoba memperbaiki hasil prediksi curah hujan hujan dengan meningkatkan akurasi yang diperoleh. Penelitian $[13,14]$ mencoba menerapkan metode lain yaitu dengan menerapkan logika fuzzy dalam melakukan prediksi curah hujan. Sejalan dengan penelitian yang telah dilakukan, penelitian ini mencoba menerapkan metode Neural Fuzzy Inference System dan algoritma pelatihan Levenberg-Marquardt dalam melakukan prediksi curah hujan. 


\section{METODE PENELITIAN}

\subsection{Deskripsi Sistem}

Sistem Prediksi curah hujan menggunakan Neural Fuzzy Inference System (NFIS) adalah logika fuzzy yang dilatih dengan menggunakan neural network dimana logika fuzzy digunakan untuk memproses input dan selanjutnya neural network digunakan untuk mengenali pola data curah hujan. Pada sistem ini, algoritma pelatihan yang digunakan pada saat melakukan proses training adalah Levenberg-Marquardt. Proses prediksi curah hujan diawali dengan membangun struktur jaringan Neural Fuzzy Inference System (NFIS), Neural Fuzzy Inference System merupakan gabungan dari 2 sistem yang berbeda yaitu: Neural Network dan Fuzzy Inference System. Bobot yang diperoleh dari proses training digunakan untuk melakukan proses testing dan proses prediksi. Pengukuran kinerja untuk melihat akurasi yang dihasilkan berdasarkan nilai MSE yang diperoleh. Secara garis besar gambaran umum sistem yang dikembangkan seperti yang ditunjukan pada Gambar 1.

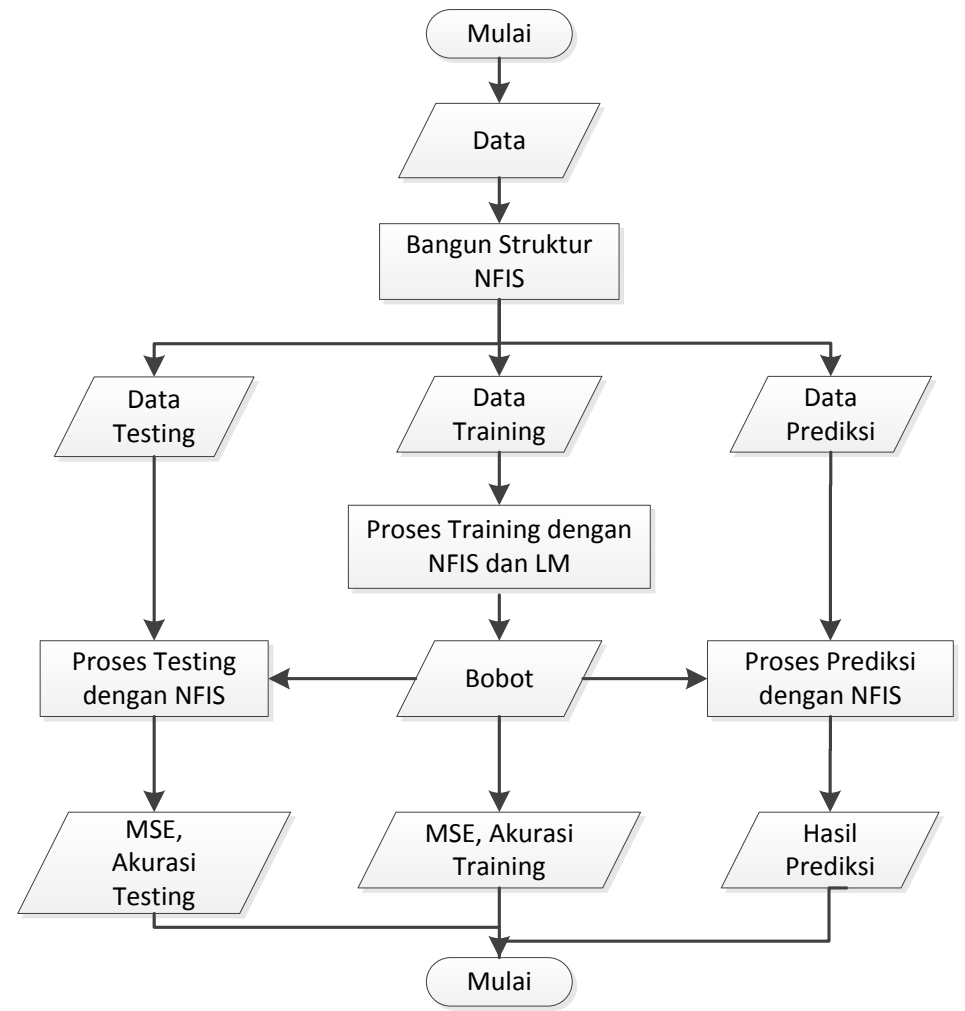

Gambar 1 Deskripsi Sistem

\subsection{Analisa data}

Periode data yang digunakan adalah dua tahun, dimulai dari 1 Januari 2013 sampai dengan 31 Desember 2014. Data masukan dibagi menjadi 2 yaitu, data training dan data testing. Data training digunakan untuk melakukan proses pelatihan yang bertujuan mendapatkan bobot yang diharapkan. Setelah bobot diperoleh, selanjutnya bobot tersebut digunakan untuk melakukan proses testing dengan data berbeda yang tidak digunakan pada saat melakukan proses training. Variabel data masukan adalah sekumpulan data dari faktor-faktor yang mempengaruhi curah hujan. Sedangkan, Variabel data keluaran merupakan keluaran yang diharapkan dari sistem. Pada sistem prediksi curah hujan ini, keluaran yang dihasilkan berupa curah hujan harian.

Ada banyak variabel yang dapat mempengaruhi terjadinya hujan yang tentunya akan berbeda bergantung pada lokasi atau wilayah yang diamati. Pada penelitian ini, variabel yang mempengaruhi curah hujan yang menjadi variabel masukan (input) adalah suhu rata-rata, kelembaban udara, kecepatan angin dan tekanan. Pada bagian ini akan dibahas terlebih dahulu 
mengenai deskripsi variabel keluaran (output) yang berupa curah hujan harian di Putussibau, Kalimantan barat. Sedangkan, untuk variabel masukan (input) yang digunakan adalah rata-rata suhu, kelembaban udara, kecepatan angin dan tekanan permukaan laut. Deskripsi variabel output dan input seperti yang ditunjukkan pada Tabel 1.

Tabel 1 Deskripsi variabel output dan input

\begin{tabular}{|l|c|c|c|c|}
\hline \multicolumn{1}{|c|}{ Variabel } & Mean & Std. Dev & Min & Max \\
\hline Curah hujan (mm) & 2.7 & 8.01 & 0 & 70 \\
\hline Suhu udara $\left({ }^{\circ} \mathbf{C}\right)$ & 27.39 & 1.24 & 22 & 34 \\
\hline Kelembaban udara (\%) & 77.27 & 6.477 & 55 & 98 \\
\hline Kecepatan angin (km/jam) & 3.38 & 2.496 & 0 & 33 \\
\hline Tekanan permukaan laut (milibar) & 1010.67 & 1.388 & 1006.60 & 1016.40 \\
\hline
\end{tabular}

Pada Tabel 1 menunjukkan bahwa dalam periode 1 Januari 2013 sampai dengan 31 Desember 2014, curah hujan rata-rata di Putussibau Kalimantan Barat sebesar $2.7 \mathrm{~mm}$. Nilai minimum curah hujan harian di Putussibau Kalimantan Barat adalah nol dimana tidak terjadi hujan sama sekali dalam satu hari. Sedangkan curah hujan maksimum yang pernah terjadi di Putussibau dalam kurun waktu tersebut terjadi pada tanggal 21 November 2014 sebesar $70 \mathrm{~mm}$.

\subsection{Arsitektur Neural Fuzzy Inference System}

Pada NFIS ini sistem logika fuzzy yang dilatih dengan jaringan syaraf tiruan. Dalam struktur NFIS terdapat 4 layer yaitu: input fuzzy layer sebagai layer pertama, fuzzy rule layer sebagai layer kedua, output fuzzy layer sebagai layer ketiga dan layer terakhir adalah output layer. Input fuzzy layer merepresentasikan variabel linguistik dari anteseden rule fuzzy dimana pada input fuzzy layer ini setiap neuron mewakili himpunan fuzzy pada setiap variabel input dan menentukan besarnya nilai derajat keanggotaan anteseden rule fuzzy. Selanjutnya, pada layer 2 yang merupakan fuzzy rule layer dimana setiap neuron pada layer 2 merepresentasikan kombinasi dari input fuzzy sets dengan penghubung "AND" digunakan untuk setiap neuron pada layer kedua yang membentuk kondisi antesenden yang dibutuhkan dalam membangun rule fuzzy. Banyaknya neuron pada lapisan ini menunjukkan banyaknya aturan yang dibentuk. Pada layer 2 operasi himpunan fuzzy yang digunakan adalah T-norm Product dengan melakukan perkalian setiap nilai keanggotaan.

Pada layer 3 adalah output fuzzy layer yang merepresentasikan konsekuen fungsi keanggotaan fuzzy. Proses pelatihan dengan menggunakan jaringan syaraf tiruan (Neural Network) terjadi antara layer 2 dan layer 3. Dimana dilakukan proses hitung maju (feedforward) dengan menggunakan fungsi aktivasi. Fungsi aktivasi yang akan digunakan adalah menggunakan fungsi aktivasi sigmoid biner. Kemudian, dilakukan proses update bobot untuk mendapatkan bobot optimal atau bobot yang diharapkan. Bobot optimal ini akan digunakan dalam melakukan proses prediksi curah hujan, sehingga dapat menghasilkan suatu prediksi yang diharapkan memiliki tingkat keakurasian yang tinggi. Proses update bobot dilakukan dengan menggunakan algoritma Levenberg-Marquardt. Proses pelatihan dengan Neural Network yang terjadi antara layer 2 dan layer 3 yang menentukan konskekuen dari fuzzy rule. Dan proses terakhir yang merupakan layer ke-4 pada struktur NFIS adalah output layer, proses ini merupakan penentuan nilai output curah hujan dalam bentuk bilangan tegas dimana dalam penelitian ini untuk mendapatkan nilai output curah hujan dengan mengambil derajat keanggotaan terbesar dari output curah hujan pada layer 3. Arsitektur jaringan Neural Fuzzy Inference System yang dikembangkan ditunjukkan pada Gambar 2. 


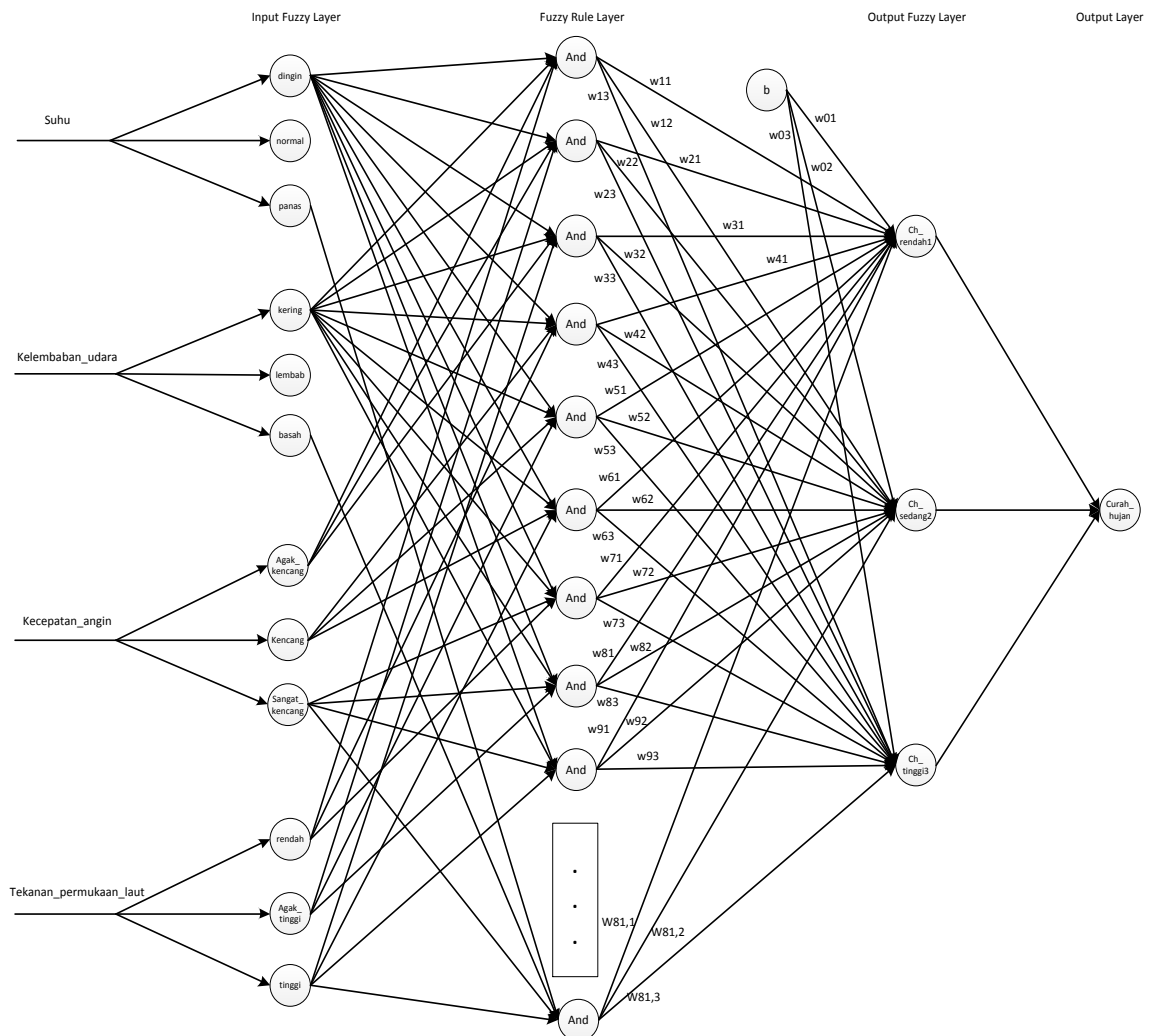

Gambar 2 Arsitektur Neural Fuzzy Inference System

\subsection{Proses Prediksi Curah Hujan}

Tahap awal pada jaringan NFIS adalah menentukan banyaknya variabel input. Selanjutnya, membentuk himpunan fuzzy variabel linguistik dari setiap variabel input dan menentukan nilai derajat keanggotaan dari setiap variabel input. Variabel input yang digunakan sebayak 4 yaitu suhu, kelembaban udara, kecepatan angin dan tekanan permukaan laut. Setiap variabel input masing-masing memiliki tiga fungsi keanggotaan. Variabel input yang pertama adalah suhu dengan tiga fungsi keanggotaan yaitu sejuk, normal dan panas dengan rentang nilai dari $22^{\circ} \mathrm{C}$ sampai $34^{\circ} \mathrm{C}$. kurva fungsi keanggotaan suhu seperti yang ditunjukkan pada Gambar 3.

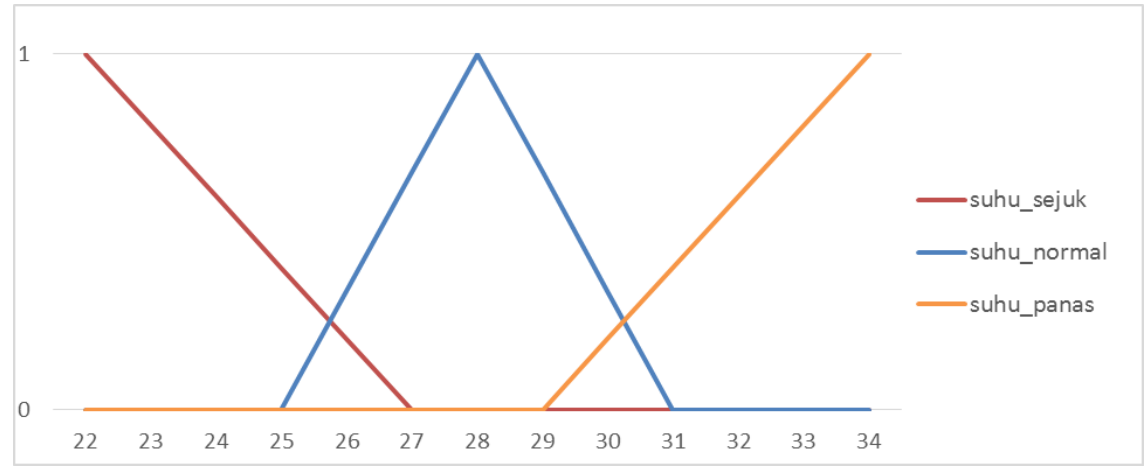

Gambar 3 Kurva fungsi keanggotaan suhu

Variabel input yang kedua adalah kelembaban udara dengan tiga fungsi keanggotaan yaitu kering, lembab dan basah dengan rentang nilai dari 55\% sampai $98 \%$. Kurva fungsi keanggotaan suhu seperti yang ditunjukkan pada Gambar 4. 


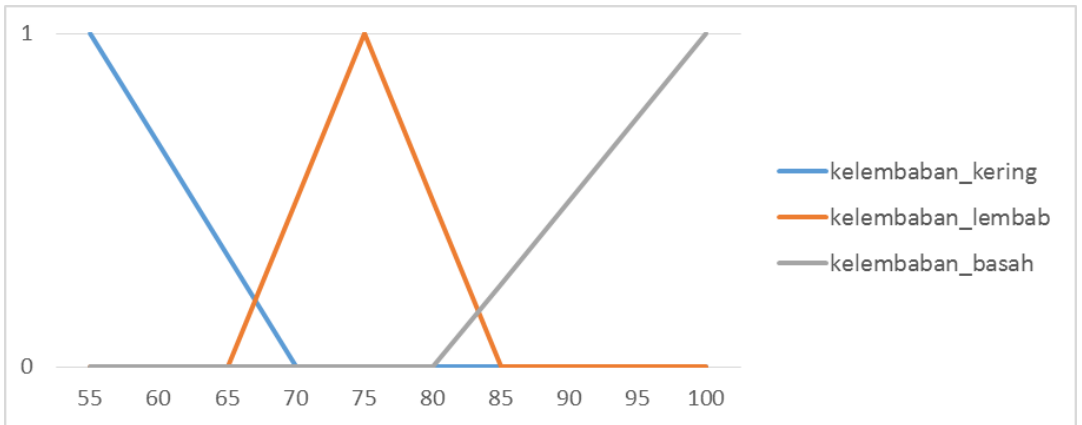

Gambar 4 Kurva fungsi keanggotaan kelembaban udara

Variabel input yang ketiga adalah kecepatan angin dengan tiga fungsi keanggotaan yaitu lambat, sedang dan kecang dengan rentang nilai dari 0 sampai $33 \mathrm{~km} / \mathrm{jam}$. Kurva fungsi keanggotaan suhu seperti yang ditunjukkan pada Gambar 5.

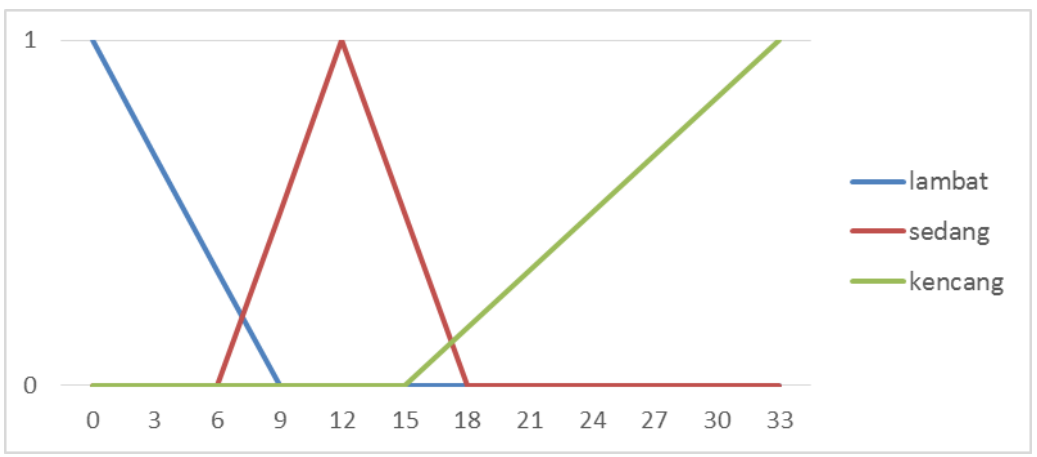

Gambar 5 Kurva fungsi keanggotaan kecepatan angin

Variabel input yang keempat adalah tekanan permukaan laut dengan tiga fungsi keanggotaan yaitu rendah, sedang dan tinggi dengan rentang nilai dari 1006.60 milibar sampai 1016.40 milibar. Kurva fungsi keanggotaan suhu seperti yang ditunjukkan pada Gambar 6 .

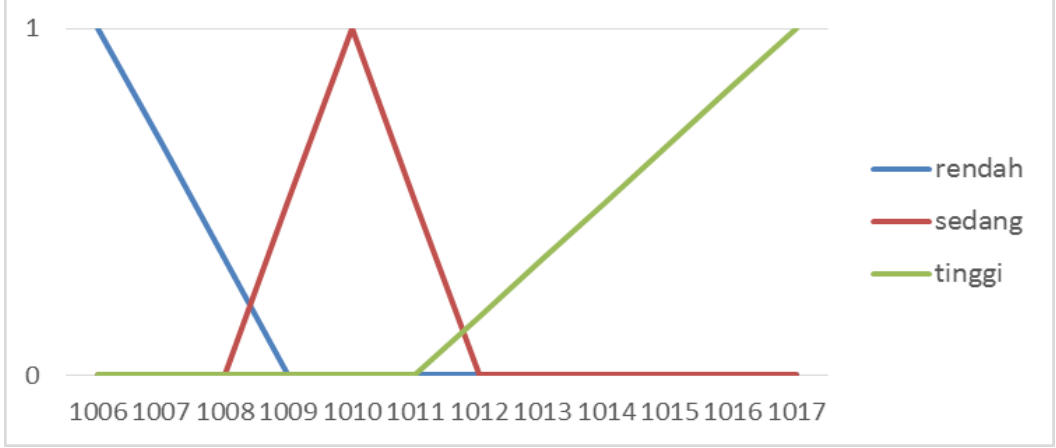

Gambar 6 Kurva fungsi keanggotaan tekanan

\subsection{Proses Training dan Testing}

Pada struktur jaringan Neural Fuzzy Inference System (NFIS) dan algoritma LevenbergMarquardt ini dilakukan proses pelatihan (training) agar dapat memperoleh bobot yang optimal. Pada sistem Neural Fuzzy Inference System ini terdapat proses training yang melakukan pembelajaran terhadap pola-pola yang dikenali. Proses training prediksi curah hujan ini menggunakan target error dan nilai MSE, nilai tersebut merupakan kuadrat kesalahan dari selisih hasil prediksi dengan data target. Proses berhenti jika nilai MSE (Mean Square Error) lebih kecil dengan target error yang telah ditentukan atau dengan maksimum epoch yang telah ditentukan dan bobot akhir diperoleh. Tahap awal proses training terlebih dahulu dilakukan inisialisasi dan parameter-parameter awal seperti inisialisasi bobot awal dengan bilangan acak kecil, parameter marquardt yang nilainya harus lebih besar dari nol $(\eta>0)$, parameter faktor tau 
$(\tau)$ yang digunakan sebagai parameter yang dikalikan atau dibagi dengan parameter marquardt, target error dan maksimum epoch. Setelah inisialisasi dilakukan, selanjutnya memproses data training yang digunakan, kemudian setiap data training yang masuk ditentukan nilai derajat keangotaanya dengan menggunakan fungsi keanggotaan.

Kemudian dilakukan operasi himpunan fuzzy dengan menerapkan T-norm Product yaitu melakukan perkalian nilai derajat keanggotaan dari input fuzzy sets. Sehingga, mendapatkan nilai neuron anteseden (ANT) pada fuzzy rule layer. Proses selanjutnya adalah proses hitung maju (feedforward), sehingga mendapatkan nilai output curah hujan. Kemudian, menghitung nilai MSE. Dalam menghitung nilai MSE langkah pertama yang dilakukan adalah menghitung nilai error dari masing-masing data. Error dihitung dengan mengurangkan data target (nilai keanggotaan fungsi curah hujan) dengan nilai output. Setelah nilai error diperoleh, maka dilakukan perhitungan untuk mendapatkan nilai MSE dengan persamaan (1).

$$
M S E=\frac{\sum_{i=1}^{n} e_{i}{ }^{2}}{n}=\frac{\sum_{i=1}^{n}\left(X_{i}-F_{i}\right)^{2}}{n}
$$

Selanjutnya, Menentukan matriks Jacobian. Matriks Jacobian tersusun dari turunan pertama fungsi error terhadap masing-masing komponen bobot. Kemudian, hitung perubahan bobot dengan menggunakan persamaan (2).

$$
\Delta w=\left[J^{T} J+\eta I\right]^{-1} * J^{T} \mathbf{e}
$$

Selanjutnya, hitung bobot baru dengan mengurangkan bobot lama dengan hasil perubahan bobot yang diperoleh. Kemudian, lakukan proses feedforward kembali dan hitung nilai MSE jaringan dengan menggunakan bobot baru. Jika MSE lebih kecil dari target error, maka bobot baru diperoleh. Namun, jika tidak lakukan pengecekan kembali, jika MSE baru kecil dari MSE lama, nilai $\eta$ akan dibagi oleh faktor $\tau$. Kemudian, kembali hitung matriks jacobian. Jika MSE baru lebih besar dari MSE lama, nilai $\eta$ akan dikalikan dengan faktor $\tau$. Selanjutnya lakukan kembali hitung perubahan bobot. Proses training dapat dilihat pada Gambar 7.
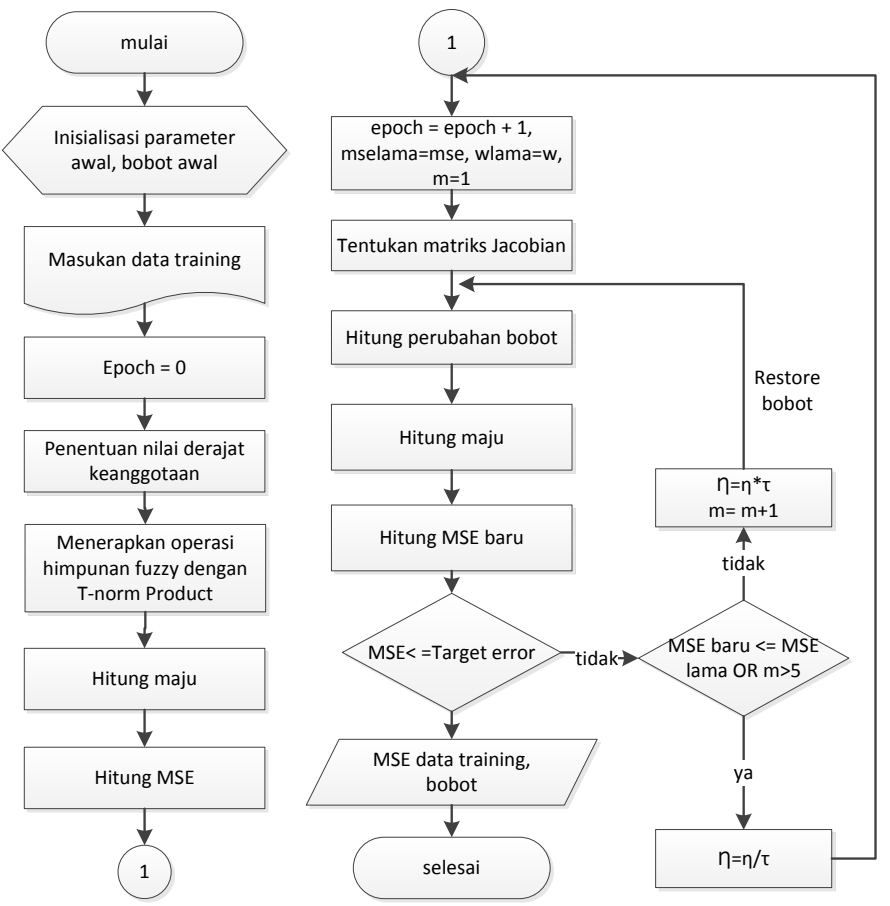

Gambar 7 Proses training dengan algoritma Levenberg-Marquardt 
Setelah melakukan proses training, maka selanjutnya dilakukan proses testing. Pada proses testing hasil prediksi akan diuji menggunakan Mean Square Error (MSE). Mean Square Error (MSE) adalah kuadrat kesalahan dari selisih hasil prediksi dengan data target curah hujan yang dibagi dengan jumlah data. Proses testing seperti yang ditunjukkan pada Gambar 8 .

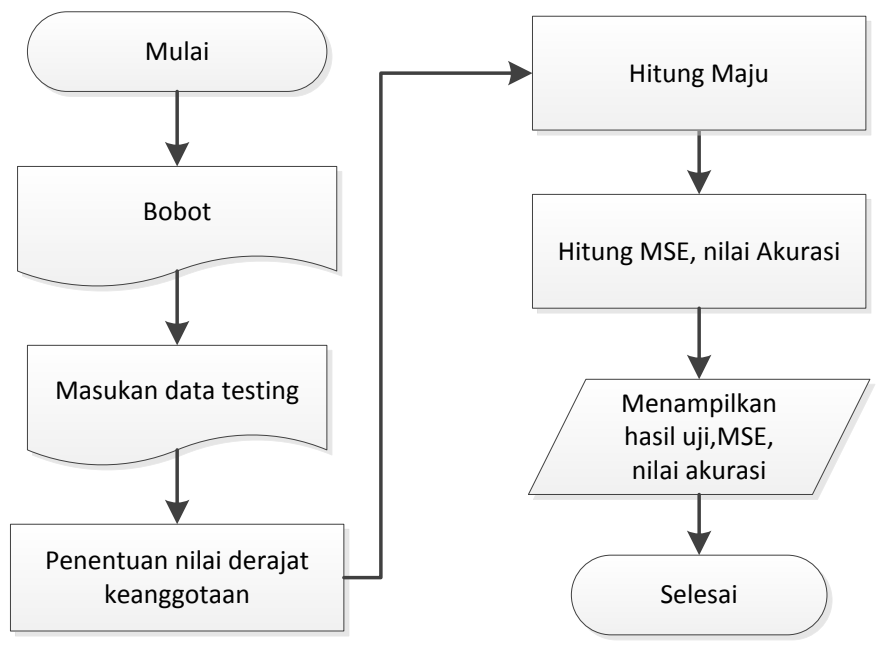

Gambar 8 Proses testing

Penjelasan skema proses testing pada Gambar 8 adalah Bobot akhir yang diperoleh pada saat proses training digunakan pada saat testing. Kemudian, dilakukan proses pengujian terhadap data uji dimana data uji merupakan data baru yang tidak digunakan pada saat training. Selanjutnya, untuk setiap data uji dilakukan proses penentuan nilai derajat keanggotaannya. Sistem akan memproses data uji dengan melakukan hitung maju hingga menampilkan hasil uji dengan menggunakan bobot yang diperoleh pada saat training. Selanjutnya, dilakukan perhitungan terhadap nilai MSE dan nilai akurasi pada saat proses testing tersebut. Semakin besar nilai MSE yang diperoleh maka hasil prediksi curah hujan menjadi tidak akurat dan demikian sebaliknya.

\section{HASIL DAN PEMBAHASAN}

Hasil penelitian yang berkaitan dengan penerapan Neural Fuzzy Inference System (NFIS) dan algoritma pelatihan Levenberg-Marquardt (LM) untuk prediksi curah hujan dengan studi kasus di stasiun pengamatan curah hujan Putussibau, Kalimantan Barat. Untuk mengetahu kinerja dari sistem prediksi maka dibangunlah sebuah model NFIS-LM yang dipengaruhi oleh beberapa faktor agar dapat menghasilkan keluaran yang lebih baik. Faktor-faktor yang mempengaruhi pada model jaringan NFIS-LM dalam prediksi antara lain adalah jumlah fungsi keanggotaan dan himpunan fuzzy variabel linguistik yang digunakan. Berdasarkan faktor-faktor tersebut, peneliti coba membandingkan dengan model fungsi keanggotaan lainnya untuk menghasilkan model jaringan NFIS-LM yang terbaik. Pada akhir analisis, hasil proses prediksi dengan model jaringan NFIS-LM terbaik yang telah dihasilkan akan dibandingkan dengan metode lain dimana metode yang dipilih adalah Neural Network dan algoritma pelatihan Backpropagation. Pengukuran kinerja yang terbaik untuk melihat kemampuan sistem prediksi berdasarkan MSE yang dihasilkan.

\subsection{Model NFIS}

Dari lima model NFIS-LM yang dikembangkan, maka hasil perbandingan model NFISLM yang telah dilakukan tersebut ditunjukkan pada Tabel 2. 
Tabel 2 Perbandingan Model NFIS-LM

\begin{tabular}{|c|l|c|c|c|}
\hline Model & \multicolumn{1}{|c|}{ Input Fuzzy Sets } & $\begin{array}{c}\text { Membership } \\
\text { Function }\end{array}$ & $\begin{array}{c}\text { MSE } \\
\text { Training }\end{array}$ & MSE Testing \\
\hline Model-1 & $\begin{array}{l}\text { SH=\{Sejuk, Normal, Panas\}, } \\
\text { KR=\{Kering, Lembab, Basah\}, } \\
\text { KA= (Lambat, Sedang, } \\
\text { Kencang\}, TPL=\{Rendah, } \\
\text { Sedang, Tinggi\} }\end{array}$ & $12 \mathrm{MF}$ & 0.0243444 & 0.0266006 \\
\hline Model-2 & $\begin{array}{l}\text { SH=\{Agak_Sejuk, Normal, } \\
\text { Panas\}, KR=\{Kering, Lembab, } \\
\text { Sangat_Basah\}, KA= } \\
\text { (Agak_Lambat, Sedang, } \\
\text { Kencang\}, TPL= } \\
\text { \{Agak_Rendah, Sedang, Tinggi\} }\end{array}$ & $12 \mathrm{MF}$ & 0.0244175 & 0.0262050 \\
\hline Model-3 & $\begin{array}{l}\text { SH=\{Sejuk, Normal, Panas\}, } \\
\text { KR=\{Kering, Lembab, } \\
\text { Sangat_Basah\}, KA=(Lambat, } \\
\text { Sedang, Sangat_Kencang\}, } \\
\text { TPL=\{Agak_Rendah, Sedang, } \\
\text { Tinggi\} }\end{array}$ & $12 \mathrm{MF}$ & 0.0243157 & 0.0263522 \\
\hline Model-4 & $\begin{array}{l}\text { SH=\{Sejuk, Normal, Panas\}, } \\
\text { KR=\{Kering, Lembab, Basah\}, } \\
\text { KA= (Lambat, Sedang, } \\
\text { Kencang\} }\end{array}$ & $9 \mathrm{MF}$ & 0.0246660 & 0.0267514 \\
\hline Model-5 & $\begin{array}{l}\text { SH=\{Agak_Sejuk, Normal, } \\
\text { Panas\}, KR=\{Kering, Lembab, } \\
\text { Sangat_Basah\}, KA= } \\
\text { (Agak_Lambat, Sedang, } \\
\text { Kencang\} }\end{array}$ & $9 \mathrm{MF}$ & 0.0248037 & 0.0263208 \\
\hline
\end{tabular}

Berdasarkan percobaan yang dilakukan maka hasil model NFIS-LM terbaik adalah model-2 dengan nilai MSE sebesar 0.0262050. Tabel perbandingan data target dan output yang dihasilkan pada model-2 dapat dilihat pada Tabel 3. Dan Grafik perbandingan data target dan output yang dihasilkan pada model-2 dapat dilihat pada Gambar 9.

Tabel 3 Perbandingan data target dan output curah hujan model-2

\begin{tabular}{|c|c|c|}
\hline No & Target Curah Hujan & Output Curah Hujan \\
\hline 1 & 0 & 2.6415438 \\
\hline 2 & 0 & 2.6415438 \\
\hline 3 & 0 & 2.5710447 \\
\hline 4 & 0 & 2.8266940 \\
\hline 5 & 0 & 2.6749640 \\
\hline 6 & 0 & 2.5710447 \\
\hline 7 & 0 & 2.6170931 \\
\hline 8 & 6 & 2.7259669 \\
\hline 9 & 0 & 1.3349587 \\
\hline 10 & 5 & 2.6477411 \\
\hline$\vdots$ & $\vdots$ & $\vdots$ \\
\hline 213 & 5 & 3.3035913 \\
\hline
\end{tabular}




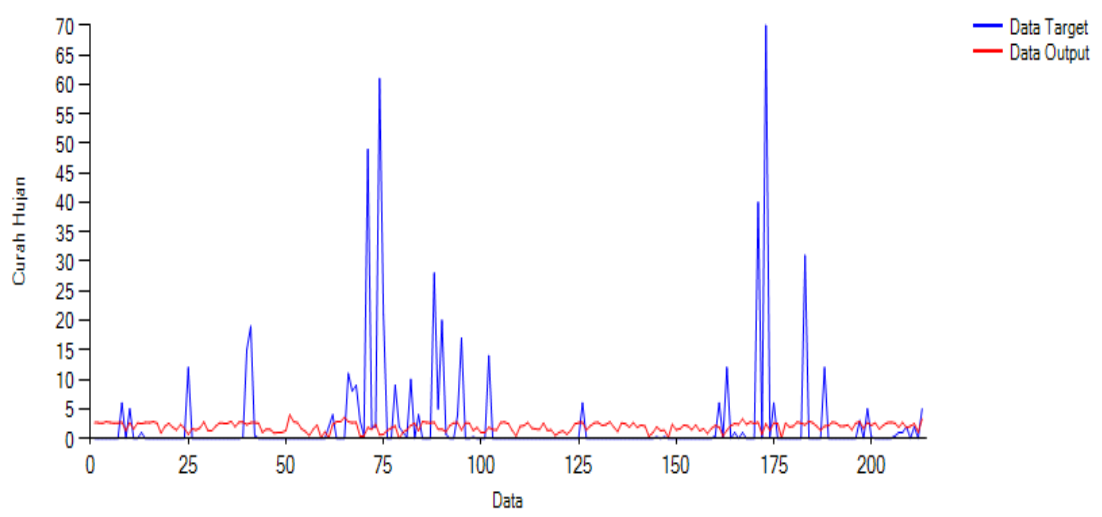

Gambar 9 Grafik perbandingan data target dan output curah hujan model-2

\subsection{Perbandingan Metode NFIS-LM dan NN-Backpropagation}

Metode Neural Fuzzy Inference System dan algoritma pelatihan Levenberg-Marquardt coba dibandingkan dengan metode lain. Metode yang dipilih untuk membandingkan hasil pengujian adalah metode Neural Network dengan menggunakan algoritma pelatihan Backpropagation. Jumlah neuron input yang digunakan pada metode ini adalah 4 yang mewakili variabel suhu rata-rata, kelembaban udara kecepatan angin dan tekanan permukaan laut. Parameter-parameter yang digunakan pada saat melakukan pelatihan adalah leraning rate sebesar 0.2, target error sebesar 0.001, jumlah maksimum epoch 50.000 dan jumlah hidden layer 1. Percobaan pada tahap training unutk mendapatkan nilai mse yang terkecil dengan melakukan percobaan terhadap jumlah node pada hidden layer dan jumlah iterasi atau epoch yang dilakukan. Tabel 4 menunjukkan perbandingan MSE yang diperoleh dari proses training.

Tabel 4 Perbandingan MSE proses training

\begin{tabular}{|c|c|c|}
\hline No & Jumlah Neuron Hidden Layer & MSE Training \\
\hline 1 & 3 & 0.0111486 \\
\hline 2 & 4 & 0.0107117 \\
\hline 3 & 7 & 0.0104712 \\
\hline
\end{tabular}

Hasil training dengan menggunakan jumlah vektor data sebanyak 512 titik, menghasilkan nilai MSE terkecil sebesar 0.0104712 dengan parameter learning rate sebesar 0.2 dan target error sebesar 0.001. Selanjutnya dilakukan proses testing untuk menguji bobot yang diperoleh pada saat training. Hasil testing dengan menggunakan jumlah vektor data sebanyak 213 menghasilkan MSE sebesar 0.0167990. Perbandingan data target dan output pada proses testing menggunakan metode Neural Network dan Backpropagation ditunjukkan pada Tabel 5.

Tabel 5 Perbandingan data target dan output curah hujan

\begin{tabular}{|c|c|c|}
\hline No & Target Curah Hujan & Output Curah Hujan \\
\hline 1 & 0 & 7.211221 \\
\hline 2 & 0 & 7.211221 \\
\hline 3 & 0 & 1.649850 \\
\hline 4 & 0 & 0.841361 \\
\hline 5 & 0 & 1.476610 \\
\hline 6 & 0 & 1.649850 \\
\hline 7 & 0 & 0.212670 \\
\hline 8 & 6 & 0.024980 \\
\hline 9 & 0 & 0.901617 \\
\hline 10 & 5 & 0.072554 \\
\hline$\vdots$ & $\vdots$ & $\vdots$ \\
\hline 213 & 5 & 1.901166 \\
\hline
\end{tabular}

IJCCS Vol. 10, No. 2, July 2016 : 125 - 136 
Selanjutnya, perbandingan data target dan hasil keluaran curah hujan diinterpretasikan melalui grafik. Hasil perbandingan data target dan hasil keluaran curah hujan menggunakan metode Neural Network dan algoritma Backpropagation ditunjukkan pada Gambar 10.

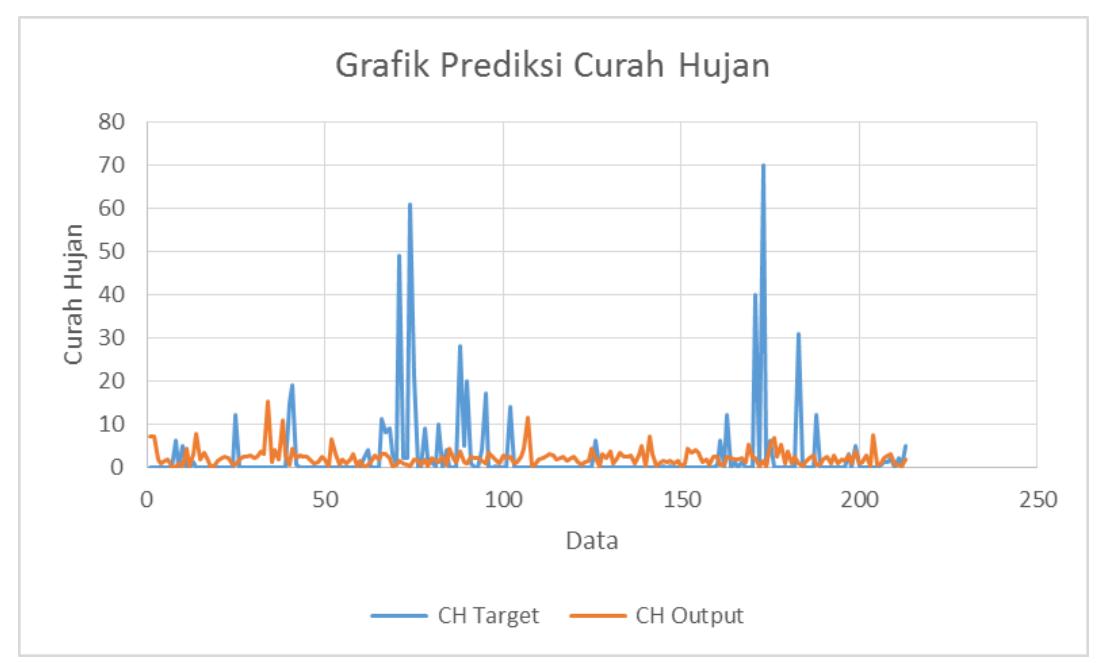

Gambar 10 Grafik Perbandingan data target dan output curah hujan

Hasil dari perbandingan pengujian metode Neural Fuzzy Inference System dan algoritma pelatihan Levenberg-Marquardt (NFIS-LM) dengan metode Neural Network dan algoritma pelatihan Backpropagation (NN-Backpropagation) ditunjukkan pada Tabel 6 .

Tabel 6 Perbandingan metode NFIS-LM dan NN-Backpropagation

\begin{tabular}{|c|l|c|c|}
\hline No & \multicolumn{1}{|c|}{ Metode } & MSE Training & MSE Testing \\
\hline 1 & NFIS-LM & 0.0244175 & 0.0262050 \\
\hline 2 & NN-Backpropagation & 0.0104712 & 0.0167990 \\
\hline
\end{tabular}

\section{KESIMPULAN}

1 Sistem yang dikembangkan dengan menggunakan metode Neural Fuzzy Inference System dan algoritma pelatihan Levenberg-Marquardt dapat memprediksi curah hujan harian.

2 Dari hasil percobaan menggunakan 5 model NFIS-LM, model NFIS-LM terbaik dengan nilai MSE terkecil diperoleh dengan dua belas fungsi keanggotaan (Membership Function) dan empat parameter masukan yaitu suhu, kelembaban udara, kecepatan angin dan tekanan permukaan laut serta variable linguistik yang digunakan adalah Suhu_Agak_Sejuk, Suhu_Normal, Suhu_Panas, Kelembaban_Kering, Kelembaban_Lembab, Kelembaban_Sangat_Basah, Kecepatan_Agak_Lambat, Kecepatan_Sedang, Kecepatan_Kencang, Tekanan_Agak_Rendah, Tekanan_Sedang dan Tekanan_Tinggi.

3 Hasil perbandingan model NFIS-LM menunjukkan akurasi yang lebih rendah dibandingkan dengan model NN-Backpropagation. Hal ini ditunjukkan dari MSE yang dihasilkan. Model NFIS-LM menghasilkan MSE sebesar 0.0262050. Sedangkan model NN-Backpropagation menghasilkan MSE sebesar 0.0167990.

\section{SARAN}

1 Perlu dilakukan pengujian dengan data yang lebih banyak, agar jaringan NFIS lebih banyak belajar dalam mengenal pola-pola baru.

2 Prediksi curah hujan dapat dikeembangkan dengan dua model, yaitu model penghujan dan model kemarau. Sehingga, persebaran data yang digunakan diharapkan lebih merata. 


\section{DAFTAR PUSTAKA}

[1] Lisa, Y., 2012, Implementasi Algoritma Pelatihan Levenberg Marquardt dan Bayes Regularisasi pada Jaringan Syaraf Tiruan untuk Prediksi Curah Hujan. Tesis, Jurusan Ilmu Komputer UGM, Yogyakarta.

[2] Asklany, S.A., Elhelow, K., Youssef, I.K. dan El-wahab, M.A., 2007, Rainfall Events Prediction using Rule-Based Fuzzy Inference System, Atmospheric Research 101, 228-236.

[3] Shu, C. dan Ouarda, T.B.M.J., 2008, Regional Flood Frequency Analysis at Ungauged Sites using the Adaptive Neuro-Fuzzy Inference System. Journal of Hydrology, 31-43.

[4] Abraham, A., Philip, N.S. dan Joseph, B., 2001, Long Term Rain Forecasting Using Soft Computing Model, Publication of the Society for Computer Simulation International, Prague, Czech Republic, 1044-1048.

[5] Gustari, I., Hadi, S. dan Renggono, F., 2012, Akurasi Prediksi Curah Hujan Harian Operasional Di Jabodetabek: Perbandingan Dengan Model WRF, Jurnal Meteorologi dan Geofisika, 119-130.

[6] Hermantoro, 2011, Pengaruh Perubahan Iklim pada Produktivitas Perkebunan Kelapa Sawit Menggunakan Model Jaringan Syaraf Tiruan, Seminar Mekanisasi Pertanian, Serpong.

[7] Hagan M.T. dan Menhaj, M.B., 1994, Training Feedforward Networks with the Marquardt Algorithm, IEEE Transactions on Neural Networks, November 1994, 989-993.

[8] Yu, H. dan Wilamowski, B.M., 2011, Advanced Learning Algorithms of Neural Networks, Disertasi, Auburn University, USA.

[9] Warsito, B. dan Sumiyati S., 2007, Prediksi Curah Hujan Kota Semarang dengan Feedforward Neural Networks Menggunakan Algoritma Quasi Newton BFGS dan Levenberg-Marquardt, Jurnal PRESIPITASI, vol 3, September 2007.

[10] Naik, A.R. dan Pathan, S.K., 2012, Weather Classification and Forecasting using Backpropagation Feed-forward Neural Networks, International Journal of Scientific and Reserch Publications, vol 2, Desember 2012.

[11] Indrabayu, Harun, N., Pallu, M.S., Achmad, A. dan Febriyati, F., 2011, Prediksi Curah Hujan di Wilayah Makassar Menggunakan Metode Wavelet-Neural Network, Jurnal ELEKTRIKAL Jurusan Teknik Elektro UNHAS, vol 9, Mei-Agustus 2011.

[12] Indrabayu, Harun, N., Pallu, M.S., Achmad, A., dan Febriyati, F., 2012, Prediksi Curah Hujan Dengan Jaringan Saraf Tiruan, Jurnal PROSIDING Fakultas Teknik UNHAS, vol 6, Desember 2012.

[13] Navianti, D.R., Usadha, I.G.N.R. dan Widjajati, F.A., 2012, Penerapan Fuzzy Inference System pada Prediksi Curah Hujan di Surabaya Utara, Jurnal Sains dan Seni ITS, vol 1, September 2012.

[14] Patel, J. dan Parekh F., 2014, Forecasting Rainfall Using Adaptive Neuro-Fuzzy Inference System (ANFIS), International Journal of Application or Innovation in Engineering Management (IJAIEM), vol 3, June 2014. 